\title{
PERSPECTIVAS E DIÁLOGOS SOBRE A EDUCAÇÃO E A ESCOLA - CONVITE À LEITURA
}

"Livre expressão: a perspectiva freinetiana de educar", de autoria de Aristeo Leite Filho, é o título do artigo encomendado desta edição e propõe alguns repensares para o tempo em que vivemos no contexto social e, como parte dele, educacional. Celèstin Freinet nos deixa como legado a possibilidade de repensar a escola e sua função formadora e inclusiva e, nesse sentido, o autor nos leva a navegar por sua obra e sua contribuição para a educação e para os processos de formação humana. Ao final do artigo, o leitor poderá acessar sugestões de leitura sobre este importante educador francês.

Falando em inclusão, Vera Nácia Duarte Franco nos instiga a pensar sobre "O desafio da inserção das tecnologias digitais na escola básica contemporânea", compartilhando um pouco da importância do uso das tecnologias como estratégia didática a ser incorporada aos processos formativos de estudantes, a partir de uma mudança de paradigmas e da formação inicial e continuada de docentes, ambas necessárias à construção de uma nova escola que seja significativa para os estudantes e que atenda às demandas do tempo presente. Ainda sobre o tema das Tecnologias da Informação e da Comunicação, Angela Fernandes Melo dialoga sobre a importância da inclusão digital como potencializadora de interações entre alunos, professores e comunidade, buscando analisar o trabalho com inclusão digital nas escolas atualmente.

Cláudia Rodrigues Arcenio traz em seu artigo "Linguagem, fala e alfabetização: uma reflexão sobre o saber linguístico do aluno" convida o leito a refletir sobre os conceitos de alfabetização e letramento, considerando processos de aquisição da língua escrita pelo viés da linguística e a valorização do falante nativo sobre sua língua materna como indispensável para a construção da língua escrita.

Em "Proposta de abordagem temática com enfoque CTS no ensino de Física: produção de energia elétrica", os autores Lidiane Campos, Frederico Cruz e Cláudio Porto apresentam uma sequencia didática para o ensino da Física para comunidade escolar do município de Angra dos Reis, considerando as modalidades de produção de energia elétrica, com ênfase na energia nuclear.

As autoras Silvia Leticia Losada da Silva e Tatiana Luna Gomes da Silva discutem a importância da afetividade no contexto da escola de jovens e adultos, a partir de pesquisa realizada em escola que oferece a modalidade Educação de Jovens e Adultos da rede estadual de educação do Rio de Janeiro no artigo "A afetividade como ferramenta pedagógica do processo e aprendizagem de jovens e adultos". Apontam a afetividade como caminho para o aprendizado e para o sucesso da relação entre alunos e entre esses e seus professores, tendo como referências Wallon, Piaget e Vygotsky.

Para encerrar a sessão Artigos desta edição, um projeto teatral entra em cena pelas mãos de Mariana Oliveira em "Espetáculo B.O 'Boletim de Ocorrência': o tema da violência entre a realidade e a ficção", a partir de trabalho desenvolvido com estudantes do Ensino Médio do Instituto de Aplicação Fernando Rodrigues da Silveira.

Vitor Nunes Caetano retorna a sessão Resenha nesta edição apresentando o livro "Humanização dos cuidados em saúde: conceitos, dilemas e práticas", organizado por Suely 
Deslandes. Tema que tem sido tão relevante aos contextos societários atuais é, certamente, mais um de nossos convites à leitura.

Chegamos a nossa décima edição. O desafio de fazer cada edição é um trabalho a muitas mãos e mentes. Por isso, anunciamos a importância de divulgarmos a e-Mosaicos, com o convite para que novos colaboradores se juntem a nós nesse movimento de tessitura de ideias, reflexões, diálogos e textos.

Boa leitura! Com a esperança de que em 2017 possamos continuar a sonhar e a trilhar caminhos que continuem contribuindo para a educação brasileira.

\section{Andrea da Paixão Fernandes}

Débora de Aguiar Lage

Editoras da e-Mosaicos - Revista Multidisciplinar de Ensino, Pesquisa, Extensão e Cultura do Instituto de Aplicação Fernando Rodrigues da Silveira (CAp-UERJ) 